\title{
Correlation between Leptin with Diastolic Function in Young Adult Obesity
}

Fauzi Akira Nugraha*, M. Rizki Akbar, Toni M. Aprami, Januar W. Martha

Department of Cardiology and Vascular Medicine, Faculty of Medicine Universitas Padjadjaran, Dr. Hasan Sadikin General Hospital, Bandung, Indonesia

${ }^{*}$ Corresponding Author:

Fauzi Akira Nugraha MD.- email: fauziakira@gmail.com

Address: Cardiac Center 7th floor, Hasan Sadikin Hospital, Jalan Pasteur No. 38, Bandung, West Java 40161, Phone: $+6222-7234158$

Manuscript submitted: August 28, 2018; Revised and accepted: February 14, 2019

\section{ABSTRACT}

Background: Obesity is one of the global health problems with increasing prevalence, and the complication is related to the alteration of the left ventricle. An obese person without symptoms has impaired diastolic function compares to a normal population, but the mechanism is still unclear. One of the evolving theories is caused by chronic inflammation, characterized by the increase of proinflammatory adipocytokines in an obese person. Leptin is a chronic inflammatory marker which is synthesized by all adipose tissues and has a positive correlation with the body mass index. Leptin level are influenced by age except young adult group. The aim of this study is to investigate the correlation between leptin level and diastolic function of the left ventricle in young adult obese.

Method: This study was conducted in a single centre with cross-sectional design. The subject of this study consists of all young adult obese, worked in Dr. Hasan Sadikin General Hospital, between June-August 2018. The diastolic function of the left ventricle was measured by examining the ventricle relaxation (E/mean $\left.e^{\prime}\right)$ by tissue doppler imaging method. The examination of leptin level was done by sandwich-ELISA test method. Pearson correlation test was done to assess the correlation between those two.

Result: This study consisted of 38 patients with the mean of age $30.75 \pm 7.25$ years old, $68 \%$ were males. The mean score of $\mathrm{E} /$ mean e' was $6.49 \pm 3.02 \mathrm{ng} / \mathrm{mL}$ and the median of leptin was $13.95(9.1-25.4) \mathrm{mg} / \mathrm{L}$. After data log transformation of leptin was done, there was a significant positive correlation $(r=0.5892, p<0.001)$ between leptin level and E/mean e'.

Conclusion: There was a significant correlation between the level of leptin and diastolic function of the left ventricle in young adult obese.

Keywords: leptin; left ventricle diastolic function; obesity; tissue Doppler imaging 


\section{INTISARI}

Latar Belakang: Obesitas merupakan salah satu masalah kesehatan global yang prevalensinya terus meningkat, salah satu komplikasinya melibatkan gangguan ventrikel kiri. Obesitas yang asimtomatik memiliki fungsi diastolik ventrikel kiri yang lebih rendah dibandingkan populasi normal. Mekanisme penurunan fungsi diastolik ventrikel kiri tersebut masih belum jelas, namun diketahui disebabkan oleh kondisi inflames kronis. yang ditandai dengan peningkatan adipositokin proinflamasi. Leptin merupakan adipositokin proinflamasi yang disintesis oleh jaringan adiposa di seluruh tubuh dan memiliki korelasi positif dengan indeks massa tubuh. Kadar leptin dipengaruhi oleh usia kecuali kelompok usia dewasa muda. Tujuan penelitian ini adalah untuk menilai hubungan kadar leptin dan fungsi diastolik ventrikel kiri pada obesitas dewasa muda.

Metode: Penelitian ini merupakan penelitian dengan rancangan potong lintang dilakukan pada seluruh obesitas dewasa muda yang bekerja di RSUP Dr. Hasan Sadikin Bandung pada bulan Juni-Agustus 2018. Pemeriksaan fungsi diastolik ventrikel kiri dilakukan dengan penilaian relaksasi ventrikel kiri yang dinilai dengan $\mathrm{E} /$ mean e' dengan teknik tissue doppler imaging. Pengukuran kadar leptin dilakukan dengan metode tes sandwich-ELISA. Analisis korelasi Pearson dilakukan untuk menilai hubungan antara keduanya.

Hasil: Penelitian ini melibatkan 38 orang dengan rata-rata usia 30,75 $\pm 7,25$ tahun dan $68 \%$ adalah laki-laki. Rata-rata nilai E/mean e' adalah 6,49 $\pm 3,02 \mathrm{ng} / \mathrm{mL}$ dan nilai median leptin adalah 13,95 $(9,1-25,4) \mathrm{mg} / \mathrm{L}$. Setelah dilakukan transformasi log pada nilai kadar leptin, maka didapatkan uji korelasi positif yang signifikan antara leptin dan E/mean e' $(r=0,5892, p<0,001)$.

Kesimpulan: Terdapat hubungan yang signifikan antara kadar leptin dan fungsi distolik ventrikel kiri pada populasi obesitas dewasa muda.

\section{INTRODUCTION}

Obesity is still global health problem and incidence continuous to increase. The prevalence continues to increase in last two decades, with a total population of obesity in 2016 is 650 million, which is around $13 \%$ of the entire adult population in the world. ${ }^{1,2}$ One of obesity complication is related to the alteration of the left ventricle. ${ }^{3}$

Obesity causes dysfunction of adipose tissue and change in regulation to synthesize and secretion of adipocytokines, increased synthesis and secretion of proinflammation adipocytokines, this condition cause the activation of inflammatory signaling pathway in the systemic circulation. Systemic effects that happen is a chronic systemic inflammatory condition that can be found in obesity. Adipocytokine which has an important role in the mechanism of systemic inflammatory on obesity among others are tumor necrosis factor- alpha (TNFa), interleukin-6 (IL-6), C-reactive protein (CRP), and leptin. Hyperleptinemia is one of the conditions that occurred in obesity and leptin is the most correlated inflammatory marker with BMI compared to other inflammatory markers. ${ }^{4-12}$

In addition to adipose tissue, leptin and its receptor isoforms are expressed in various other tissues. These include cardiovascular tissues, such as endothelial cells, ${ }^{13}$ smooth muscle cells, ${ }^{14}$ and cardiomyocytes. ${ }^{15}$ These findings suggest that leptin has specific effect on myocardium. ${ }^{16}$ Leptin level are influenced by age except young adult group. Considering cardiac structure and function, leptin levels have been suggested to be associated with left ventricular hypertrophy, ${ }_{17}^{17}$ increased myocardial wall thickness, ${ }^{18}$ and impaired cardiac contractile function. ${ }^{19}$ Indeed, elevated leptin 
levels have been associated with heart failure in patients with both reduced and preserved ejection fraction. ${ }^{20-22}$ Recent study showed that high leptin levels are independently associated with diastolic dysfunction in the general population, especially in women. ${ }^{23}$

Thus, leptin exhibits a wide range of cardiovascular effects and is associated with cardiovascular outcome. The association between leptin and cardiovascular diseases could emerge from direct cellular effects in both cardiac and vascular tissues. To our knowledge the association between leptin levels and cardiac structure and function has not been studied in young adult obese population. Therefore, we tested the hypothesis that leptin levels are associated with cardiac function in patients with obese in young adult group.

\section{METHODS}

\section{Study population}

A total of 67 consecutive obese person works in Dr. Hasan Sadikin General Hospital, Bandung between June-August 2018 were included in this cross-sectional study. Obese person aged between 20-39 years old were included in the study, whereas obese with diabetes mellitus, hypertension, hypertensive heart disease, arrhythmia, coronary artery disease, congenital heart disease, valvular heart disease, all type of cardiomyopathy, pericardial disease, myocarditis, heart failure, infection, malignancy and poor echocardiography window during examination were excluded.

Written informed consent was obtained from each subject following a detailed explanation of the objective and protocol of the study which was conducted in accordance with the ethical principles stated in the "Declaration of Helsinki", this study was approved by the institutional ethic committee.

Leptin measurement and echocardiography
After fulfilling the inclusion and exclusion criteria, subject underwent several data collection such as patient demographics (age, gender) anthropometrics (height, weight, body mass index (BMI), upper arm circumference). BMI was calculated as weight $(\mathrm{kg})$ divided by height squared $\left(m^{2}\right)$.

Venous blood samples were drawn into EDTA tubes after a 12-h overnight fast using standardized methods. Plasma leptin levels were determined by a commercial enzymelinked immunosorbent assay kit (BioVendor; Cat No: RD 191001100, USA).

Two-dimensional, M-mode, and Doppler echocardiography were performed according to the American Society of Echocardiography (ASE) guidelines by one cardiologist utilising a Philips Affiniti 50 ultrasound machine. The echocardiographic parameters chosen for further study were left ventricular mass index (LVMI), left ventricular ejection fraction (EF), left atrium diameter (LAD), left atrium volume index (LAVI) measured by dividing LA volume by both body surface area (BSA). Tissue Dopplerderived peak early diastolic septal mitral annular velocity (e'), ratio of peak early diastolic mitral velocity to tissue Doppler-derived peak early diastolic mitral annular velocity (E/e').

Statistical analysis

The statistical analysis was performed using computer software (SPSS version 21.0, SPSS Inc. Chicago, IL, USA). For numerical data, the data distribution tested using the Shapiro-Wilk method. Data that was normally distributed in the univariate analysis were expressed in mean and standard deviation, while data with abnormal sample distribution are expressed in median with range. Bivariate analysis was carried out after the univariate analysis to see the relationship between two variables. If the variables showed normal data distribution, then bivariate analysis was done using Pearson correlation and if it was not normal Spearman rank was 
used. The $p$ value was less than 0.05 that considered statistically significant.

\section{RESULT}

The study sample comprised 38 patients (mean (SD) age $31 \pm 7$ years, $68 \%$ male). Of the total 67 subjects, 29 patients were excluded because 4 patients have hypertension, 3 patients have diabetes mellitus, 1 patient has valvular heart disease, 18 patients with poor echocardiography window and 3 patients refuse to participate. Median for BMI was $33.71(30-43) \mathrm{kg} / \mathrm{m}^{2}$, median for upper arm circumference was $34(30-40) \mathrm{cm}$ for men and 36 (30$45) \mathrm{cm}$ for women.

Echocardiography parameters of the subject are presented in table 1. Mean LVEDd in this study was $50.6 \pm 0.51 \mathrm{~mm}$ for male and $48.3 \pm 0.64$ $\mathrm{mm}$ for female, mean LAd in this study was $3.55 \pm 0.51 \mathrm{~mm}$, mean LVEF was $67.68 \pm 6.26 \%$. Diastolic function parameters were stated in table 1 . Mean mitral $E$ velocity in this study was $81.1 \pm 26.9 \mathrm{~cm} / \mathrm{s}$, mean of mean $\mathrm{e}^{\prime}$ in this study was $11.85 \pm 5.15 \mathrm{~cm} / \mathrm{s}$. Median leptin level in this study was 13.95 (9.1-25.4) ng/mL.

Bivariate analysis was

performed using Spearman rank between leptin level and E/mean e' ratio, and resulted with $r$ value $=0.598$, $p<0.001$ (table 2). The result of bivariate analysis showed that there was a positive correlation between the leptin and E/mean e'. The determinant coefficient value $R^{2}$ was 0.357 which meant that the leptin after being controlled by confounding can explain the variability of diastolic function using E/mean e' ratio by $35 \%$, while the rest was influenced by other factors (figure $1)$.

\section{DISCUSSION}

In the present study we have shown a clear association between leptin levels and left ventricular diastolic filling in young adult obese population. High fasting plasma leptin levels were associated with one of markers of impaired diastolic function. To our knowledge, the association between high leptin levels and impaired diastolic function has not been previously reported in young adult obese population.

We found a correlation between leptin and diastolic function with exclusion of confounding factors such as hypertension, diabetes mellitus, coronary artery disease and age limitation. These result support previous studies about correlation between leptin and diastolic function such as Puurunen et al. ${ }^{24}$, Kamimura et al. ${ }^{25}$, and FontesCarvalho et al. ${ }^{23}$.

Puurunen et al. conducted a study in Finland, the study using coronary artery disease (CAD) population and was divided in 4 quartiles based on the leptin. ${ }^{24}$ Based on this study elevated plasma leptin levels are associated with impaired left ventricular diastolic function in patients with CAD independently of obesity and other confounding variables. Leptin may be one of the mechanistic links explaining the development of congestive heart failure in obese subjects. ${ }^{24}$

The results in this research show that there is a negative correlation between leptin levels with left ventricular diastolic function using $E /$ mean e' ratio parameter $(r=-0.589$, $p<0.001)$, so it can be concluded that the higher levels of leptin will cause the higher the parameter of E/mean e' ratio. Results of this study in related with other study conducted by the year 2018 from Kamimura et al. ${ }^{25}$ in the normal population. Kamimura et al. stated that increased levels leptin correlated negatively with diastolic left ventricular function assessed with diastolic wall strain (DWS) were examined by echocardiography modalities. This research suggested that the conditions of inflammation has crucial role in decreasing function of the myocardium.

This study could not assess how the direction of the relationship of leptin and diastolic function parameters of 
Table 1. Baseline characteristics

\begin{tabular}{|c|c|}
\hline Characteristics & $\begin{array}{l}\text { Total } \\
\mathrm{n}=38\end{array}$ \\
\hline Age (year), mean $\pm S D$ & $30.75 \pm 7.25$ \\
\hline \multicolumn{2}{|l|}{ Gender, n (\%) } \\
\hline Male & $26(68)$ \\
\hline Female & $12(32)$ \\
\hline BMI $\left(\mathrm{kg} / \mathrm{m}^{2}\right)$, Median $(\min -\max )$ & $33.71(30-43)$ \\
\hline \multicolumn{2}{|l|}{ Upper arm circumference } \\
\hline Male (cm), Median (Min - Max) & $34(30-40)$ \\
\hline Female (cm), Median (Min - Max) & $36(30-45)$ \\
\hline \multicolumn{2}{|l|}{ Echocardiography parameter } \\
\hline Left atrium diameter $(\mathrm{mm})$, mean $\pm \mathrm{SD}$ & $3.55 \pm 0.95$ \\
\hline \multicolumn{2}{|l|}{ Left ventricle end diastolic diameter (LVEDd) } \\
\hline Male $(\mathrm{mm})$, mean $\pm S D$ & $50.60 \pm 0.51$ \\
\hline Female $(\mathrm{mm})$, mean $\pm \mathrm{SD}$ & $48.30 \pm 0.64$ \\
\hline \multicolumn{2}{|l|}{ Left ventricle mass index (LVMI) } \\
\hline Male $\left(\mathrm{g} / \mathrm{m}^{2}\right)$, mean $\pm S D$ & $78.21 \pm 5.80$ \\
\hline Female $\left(\mathrm{g} / \mathrm{m}^{2}\right)$, mean $\pm S D$ & $96.48 \pm 7.31$ \\
\hline LVEF $(\%)$, mean $\pm S D$ & $67.68 \pm 6.26$ \\
\hline $\begin{array}{l}\text { Left atrium volume index }\left(\mathrm{ml} / \mathrm{m}^{2}\right) \text {, mean } \pm S D \\
\text { Mitral E velocity }(\mathrm{cm} / \mathrm{s}) \text { mean } \pm S D\end{array}$ & $\begin{array}{l}17.75 \pm 13.15 \\
81.10 \pm 26.90\end{array}$ \\
\hline Septal e' (cm/s),mean \pm SD & $10.05 \pm 5.95$ \\
\hline Lateral e' $(\mathrm{cm} / \mathrm{s})$, mean $\pm S D$ & $14.70 \pm 4.70$ \\
\hline
\end{tabular}

$\mathrm{SD}=$ standard deviation ; $\mathrm{BMI}=$ body mass index; $\mathrm{LVEF}=$ left ventricular ejection fraction

E/mean e' ratio, namely whether leptin's role is as a cause or as a marker. Previous theories stated that the role of leptin as a cause of decreased diastolic left ventricular function were: (1) leptin has the effect of profibrotic against the heart that can increase the levels of collagen in the extracellular matrix in muscle cells of the heart and the advent of changes in the heart muscle cell biology, ${ }^{24}$ (2) leptin can cause interference to systems renin-angiotensin-aldosterone, renin-angiotensin in disorderaldosterone can increase collagen in extracellular matrix of the cardiac muscle cells effect on increasing the rigidity myocyte. ${ }^{26}$

Correlation of leptin level and left ventricular diastolic function is supported by the research of the large cohort studies conducted by FontesCarvalho et al. ${ }^{23}$ asserting that leptin as a cause of decreased in left ventricular diastolic function based on the results of studies which found that higher leptin level associated with decreased in diastolic function measured by echocardiography using Tissue doppler imaging (TDI) in follow up for 5 years. The association was independent of age, gender, ethnicity, systolic blood pressure, heart rate, smoking status, and BMI.

Table 2. Bivariate analysis

\begin{tabular}{lll}
\hline & E/mean e' ratio (average) & \\
\cline { 2 - 3 } & Coefficient $\mathbf{R}(\mathbf{9 5 \%} \mathrm{Cl})$ & $\mathbf{P}$ value \\
\hline Log. Leptin & $0.589(0.332-0.765)$ & $<0.001$ \\
\hline
\end{tabular}




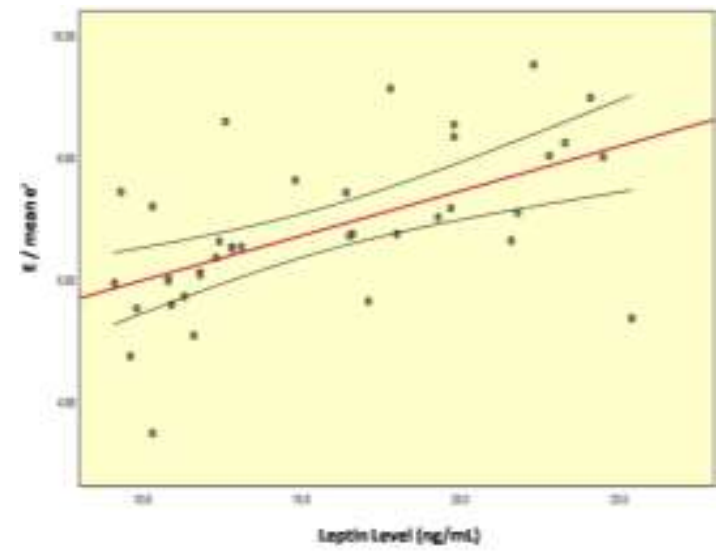

Figure 1. Scatter plot showing correlation between leptin and E/mean e' ratio

The theory of leptin as a cause of decreased diastolic left ventricular function is also supported by experimental studies conducted by Abe et al. ${ }^{27}$ doing the study that states that exposure to leptin against the heart muscle cells cause changes the structure of the heart muscle cells than mice without leptin exposure groups. The research was also supported by Madani et al. ${ }^{28}$ who conducted research on experimental mice with leptin exposure in the heart muscle cells causes changes in the structure of the heart muscle cells than mice without the exposure groups leptin.

There are several limitations in this study. Analysis of influence of gender between leptin and diastolic function cannot be measured due to unbalance participant in both groups. Due to the design of this study, further analysis through a prospective cohort study and length of obese is needed to explain whether a high leptin is the cause of the decrease diastolic function.

\section{CONCLUSION}

There was a significant correlation between leptin level and diastolic function in young adult obesity. The higher leptin level, the lower diastolic function.

\section{DISCLOSURE AND ETHICS}

No potential conflict of interest in this study.

\section{REFERENCES}

1. World Health Organization. Obesity and overweight. 2017. Tersedia dari: http://www.who.int/mediacentre/ factsheets/fs311/en/.

2. Seidell J.C., Rissanen A.M. 2014. Prevalence of obesity in adults: The Global Epidemic. In: Bray G.A., Bouchard C., editor. Handbook of Obesity: Epidemiology, Etiology, and Physiopathology. United States of America: Taylor\&Francis, pp. 93-107.

3. Arroyo-Johnson C., Mincey K.D. 2016. Obesity epidemiology worldwide. Gastroentero Clin, 45:571-579.

4. Rocha V.Z., Folco E.J. 2011. Inflammatory concepts of obesity. Int J inflamm, 2011:529061

5. Calabro P., Chang D.W., Willerson J.T., Yeh E.T. 2005. Release of C-reactive protein in response to inflammatory cytokines by human adipocytes: linking obesity to vascular inflammation. J Am Coll Cardiol, 46:1112-1113.

6. Conde J., Scotece M., Gómez R., López V., Gómez-Reino J.J., Lago F., et al. 2011. Adipokines: biofactors from white adipose tissue. A complex hub among inflammation, metabolism, and immunity. Biofactors, 37:413420. 
7. Lastra G., Sowers J.R. 2013. Obesity and cardiovascular disease: role of adipose tissue, inflammation, and the reninangiotensin-aldosterone system. Horm Mol Biol Clin Investig, 15:49-57.

8. Tilg H., Moschen A.R. 2010. Inflammatory and antiinflammatory mediators secreted by adipose tissue. In: Awad A, Bradford P, editor. Adipose Tissue and Inflammation, 1st edition. Boca Raton: Taylor \& Francis, pp. 6676.

9. Wang Z., Nakayama T. 2010. Inflammation, a link between obesity and cardiovascular disease. Mediators Inflamm, 2010; 2010:535918..

10. Gregor M.F., Hotamisligil G.S. $2011 . \quad$ Inflammatory mechanisms in obesity. Ann Rev Immunol, 29:415-445.

11. Jung U.J., Choi M.S. 2014. Obesity and its metabolic complications: the role of adipokines and the relationship between obesity, inflammation, insulin resistance, dyslipidemia and nonalcoholic fatty liver disease. Int J Mol Sci, 15:61846223.

12. Bondia-Pons I., Ryan L., Martinez J.A. 2012. Oxidative stress and inflammation interactions in human obesity. $\mathrm{J}$ Physiol Biochem, 68:701-711.

13. Sierra-Honigmann M.R., Nath A.K., Murakami C., GarcíaCardeña G., Papapetropoulos A., Sessa W.C., et al. 1998. Biological action of leptin as an angiogenic factor. Science, 281:1683-1686.

14. Oda A., Taniguchi T., Yokoyama M. 2001. Leptin stimulates rat aortic smooth muscle cell proliferation and migration. Kobe J Med Sci, 47:141-150.

15. Rajapurohitam V., Gan X.T., Kirshenbaum L.A., Karmazyn M. 2003. The obesity-associated peptide leptin induces hypertrophy in neonatal rat ventricular myocytes. Circulation Res, 93:277-279.

16. Schulze P.C., Kratzsch J. 2005. Leptin as a new diagnostic tool in chronic heart failure. Clin Chim Acta, 362:1-11.

17. Ghantous C., Azrak Z., Hanache S., Abou-Kheir W., Zeidan A. 2015. Differential role of leptin and adiponectin in cardiovascular system. Int $\mathrm{J}$ Endocrinol, 2015;2015:534320.

18. Paolisso G., Tagliamonte M.R., Galderisi M., Zito G.A., Petrocelli A., Carella C., et al. 1999. Plasma leptin level is associated with myocardial wall thickness in hypertensive insulin-resistant men. Hypertension,34:1047-1052.

19. Nickola M.W., Wold L.E., Colligan P.B., Wang G.J., Samson W.K., Ren J. 2000. Leptin attenuates cardiac contraction in rat ventricular myocytes: role of NO. Hypertension, 36:501-505.

20. Leyva F., Anker S., Egerer K., Stevenson J., Kox W., Coats A. 1998. Hyperleptinaemia in chronic heart failure: relationships with insulin. Eur Heart J, 19:1547-1551.

21. Schulze P.C., Kratzsch J., Linke A., Schoene N., Adams V., Gielen S., et al. 2003. Elevated serum levels of leptin and soluble leptin receptor in patients with advanced chronic heart failure. Eur J Heart Fail. 5:33-40.

22. El-Aziz T.A.A., Mohamed R.H., Mohamed R.H., Pasha H.F. 2012. Leptin, leptin gene and leptin receptor gene polymorphism in heart failure with preserved ejection fraction. Heart Vessels, 27:271-279.

23. Fontes-Carvalho R., Pimenta J., Bettencourt P., Leite-Moreira A., Azevedo A. 2015. Association between plasma leptin and adiponectin levels and diastolic 
function in the general population. Expert Opin Ther Targets, 19:1283-1291.

24. Puurunen V., Lepojärvi E., Piira O., Hedberg P., Junttila M., Ukkola O., et al. 2016 High plasma leptin levels are associated with impaired diastolic function in patients with coronary artery disease. Peptides, 84:17-21.

25. Kamimura D., Suzuki T., Wang W., Hall J.E., Winniford M.D., Kullo I.J., et al. 2018. Higher plasma leptin levels are associated with reduced left ventricular mass and left ventricular diastolic stiffness in black women: insights from the Genetic Epidemiology Network of Arteriopathy (GENOA) study.
Hypertens Res, 41:629-638.

26. Bornstein S.R., Torpy D.J. 1998. Leptin and the reninangiotensin-aldosterone system. Hypertension, 32:376-377.

27. Abe Y., Ono K., Kawamura T., Wada H., Kita T., Shimatsu A., et al. 2007. Leptin induces elongation of cardiac myocytes and causes eccentric left ventricular dilatation with compensation. Am J Physiol Heart Circl Physiol, 292:H2387H96.

28. Madani S., De Girolamo S., Muñoz D.M., Li R.K., Sweeney G. 2006. Direct effects of leptin on size and extracellular matrix components of human pediatric ventricular myocytes. Cardiovasc Res, 69:716-725. 